\title{
Renal cell carcinoma: a review of biology and
}

\section{pathophysiology [version 1; peer review: 2 approved]}

\author{
Shahzaib Nabi, Elizabeth R. Kessler, Brandon Bernard, Thomas W. Flaig, \\ Elaine T. Lam (D)
}

Division of Medical Oncology, Anschutz Medical Campus, University of Colorado Denver, Aurora, CO, USA

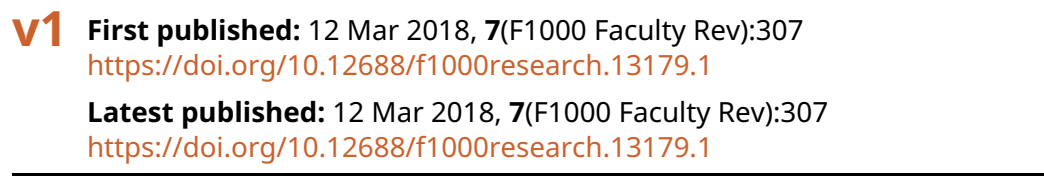

\section{Abstract}

Over the past decade, our understanding of the biology and pathophysiology of renal cell carcinoma (RCC) has improved significantly. Insight into the disease process has helped us in developing newer therapeutic approaches toward RCC. In this article, we review the various genetic and immune-related mechanisms involved in the pathogenesis and development of this cancer and how that knowledge is being used to develop therapeutic targeted drugs for the treatment of RCC. The main emphasis of this review article is on the most common genetic alterations found in clear cell RCC and how various drugs are currently targeting such pathways. This article also looks at the role of the immune system in allowing the growth of RCC and how the immune system can be manipulated to reactivate cytotoxic immunity against RCC.

\section{Keywords}

renal cell carcinoma, biology, von Hippel Lindau, VHL, PBRM-1, BAP-1, HIF, mTOR, Glutaminase, Immunotherapy

\section{Open Peer Review}

Approval Status

1 2

version 1

12 Mar 2018

Faculty Reviews are review articles written by the prestigious Members of Faculty Opinions. The articles are commissioned and peer reviewed before publication to ensure that the final, published version is comprehensive and accessible. The reviewers who approved the final version are listed with their names and affiliations.

\section{Mehdi Mollapour, SUNY Upstate Medical} University, Syracuse, USA

2. James J. Hsieh, Siteman Cancer Center, Washington University, St. Louis, USA Any comments on the article can be found at the end of the article. 
Corresponding author: Elaine T. Lam (elaine.lam@ucdenver.edu)

Author roles: Nabi S: Conceptualization, Project Administration, Writing - Original Draft Preparation, Writing - Review \& Editing; Kessler ER: Conceptualization, Writing - Review \& Editing; Bernard B: Conceptualization, Writing - Review \& Editing; Flaig TW:

Conceptualization, Writing - Review \& Editing; Lam ET: Conceptualization, Project Administration, Resources, Supervision, Writing -

Original Draft Preparation, Writing - Review \& Editing

Competing interests: ETL receives kidney cancer clinical trial funding from Argos, Bristol-Myers Squibb, Calithera, Genentech, Merck, Peloton, Pfizer, and Roche; has served as a consultant for Bristol-Myers Squibb; and serves on the Independent Data Monitoring Board for Calithera. ERK receives kidney cancer clinical trial funding from Bristol-Myers Squibb. TWF receives clinical trial funding from BristolMyers Squibb, Novartis, Pfizer, Bavarian Nordic, Cougar Biotechnology, Dendreon, GTx, Janssen Oncology, Medivation, Sanofi, Genentech, Roche, Exelixis, Aragon Pharmaceuticals, Sotio, Tokai Pharmaceuticals, Astra-Zeneca/MedImmune, Lilly, Astellas, Agensys, and Seattle Genetics and has served as a consultant for GTx.

Grant information: ETL receives funding support from the National Institutes of Health/National Cancer Institute Paul Calabresi Award in Clinical Oncology Research (K12CA086913).

The funders had no role in study design, data collection and analysis, decision to publish, or preparation of the manuscript.

Copyright: (c) 2018 Nabi S et al. This is an open access article distributed under the terms of the Creative Commons Attribution License, which permits unrestricted use, distribution, and reproduction in any medium, provided the original work is properly cited.

How to cite this article: Nabi S, Kessler ER, Bernard B et al. Renal cell carcinoma: a review of biology and pathophysiology [version 1; peer review: 2 approved] F1000Research 2018, 7(F1000 Faculty Rev):307 https://doi.org/10.12688/f1000research.13179.1

First published: 12 Mar 2018, 7(F1000 Faculty Rev):307 https://doi.org/10.12688/f1000research.13179.1 


\section{Introduction}

Renal cell carcinoma (RCC) is a heterogeneous group of cancers arising from renal tubular epithelial cells that encompasses $85 \%$ of all primary renal neoplasms ${ }^{1,2}$. The most common subtypes of RCC are clear cell RCC (ccRCC), papillary RCC, and chromophobe $\mathrm{RCC}^{1}$. The remaining $15 \%$ of tumors of the kidney consist of transitional cell carcinoma (8\%), nephroblastoma or Wilms' tumor (5-6\%), collecting duct tumors $(<1 \%)$, renal sarcomas $(<1 \%)$, and renal medullary carcinomas $(<1 \%)$. The incidence of RCC varies widely in different parts of the world, and the highest incidences are in North America and the Czech Republic $^{2}$. In the US, there are 64,000 new cases of RCC and 14,000 RCC-related deaths each year ${ }^{3}$. Age, race, and gender also play a role in this disease. RCC is more common in males above the age of 60 (median age for RCC is 65), and the highest incidence is in the sixth to eighth decades of life ${ }^{4}$. Within the US, Caucasians, African-Americans, Hispanics, and Native Americans have a higher incidence of RCC as compared with Asian-Americans or Pacific Islanders ${ }^{5,6}$.

Multiple risk factors for RCC along with their pathophysiologic mechanisms have been described. These include both genetic and acquired risk factors. The two most common genes involved in the pathogenesis of RCC are the Von Hippel-Lindau (VHL) gene and the protein polybromo-1 (PBRM-1) gene. These will be discussed separately in this article. The most common acquired risk factors for RCC are smoking, hypertension, obesity, chronic analgesic use, and diabetes ${ }^{7}$.

\section{Genetic alterations in renal cell carcinoma}

The most common genetic alteration associated with the development of ccRCC is loss of the short arm of chromosome 3 (loss of $3 \mathrm{p}$ ). This alteration is seen in approximately $95 \%$ of cases of ccRCC. The most common genes involved in the pathogenesis of ccRCC include VHL, PBRM-1, SETD2, BAP-1, $K D M 5 C$, and $M T O R^{1,8}$. Other genetic alterations include gain of $5 \mathrm{q}(69 \%)$, partial loss of $14 \mathrm{q}(42 \%)$, $7 \mathrm{q}$ gain $(20 \%)$, 8 p deletion (32\%), and 9p loss $(29 \%)^{8}$.

\section{Von Hippel-Lindau gene}

$V H L$ is a tumor suppressor gene that plays a pivotal role in the development of ccRCC. VHL can be altered and transmitted in an autosomal dominant fashion (VHL disease) or in a sporadic manner. Although inherited VHL disease is rare, understanding the molecular basis of VHL disease and the identification of the VHL suppressor gene have provided great insight into the pathogenesis of sporadic disease. It is estimated that $50-60 \%$ of patients with sporadic ccRCC have an abnormality of the $V H L$ gene $^{9-11}$. Other, more sophisticated studies have suggested that $V H L$ gene alterations through genetic and epigenetic mechanisms can be found in up to $90 \%$ of ccRCC cases $^{12}$.

A "two-hit" hypothesis has been described and validated in patients with VHL disease-related development of RCC (and other tumors). Based on this hypothesis, individuals with VHL disease are born with one inactivated copy of the VHL gene in all cells while the other copy of the gene is normal. For tumorigenesis to take place, there must be a loss of function of the second gene copy as well. This "second hit" usually takes place as a result of somatic mutation or deletion of the allele. In patients with sporadic RCC, inactivation of both VHL alleles usually takes place via somatic mutations.

The product of the $V H L$ gene is a protein called pVHL, which acts as a tumor suppressor protein. VHL protein forms complexes with several other proteins in the cell, including elongin $\mathrm{B}$, elongin $\mathrm{C}$, and cellulin 2. The resulting complex (called the VBC complex) helps in the proteasomal degradation of several intracellular proteins. One of the major functions of the VHL gene product is regulating the levels of several intracellular proteins, including hypoxia-inducible factor 1 alpha and 2 alpha (HIF1A and HIF2A) $)^{13,14}$. These intracellular proteins, when bound with each other, serve as transcription factors by binding to the DNA, resulting in upregulation of messenger RNA (mRNA) that codes for several growth factors, including vascular endothelial growth factor (VEGF), platelet-derived growth factor beta (PDGFB), and transforming growth factor alpha (TGFA). These growth factors play a vital role in the development of highly vascular tumors (such as ccRCC) associated with VHL gene alterations. The mRNA also codes for other proteins and enzymes responsible for controlling proteins in the extracellular matrix.

Under normal oxygen tension, HIF1A and HIF2A are hydroxylated on proline residues and bind the pVHL, resulting in polyubiquitination of HIFA, which targets it for proteasomal degradation (Figure 1) ${ }^{15,16}$. Under conditions of hypoxemia or in the absence of pVHL, hydroxylation of HIF1A and HIF2A does not occur and HIFA accumulates in the cell and dimerizes with hypoxia-inducible factor beta (HIFB). The HIFA-HIFB complex then migrates to the nucleus and acts as a transcription factor, resulting in increased mRNA levels coding for VEGF, PDGFB, TGFA, erythropoietin, and extracellular matrix proteins ${ }^{14,17}$.

From a therapeutic standpoint, inhibitors of VEGF are typically used as first-line therapy for the treatment of metastatic ccRCC. Sunitinib and pazopanib are two commonly used tyrosine kinase inhibitors that target and block vascular epidermal growth factor receptor (VEGFR) ${ }^{18,19}$. Axitinib, cabozantinib, lenvatinib, and sorafenib are other tyrosine kinase inhibitors that block VEGFR. Bevacizumab, a monoclonal antibody that directly targets VEGF, is also a treatment option for ccRCC. In addition, drugs that block HIFA would theoretically block this pathway, resulting in a decrease in the production of angiogenic factors (such as VEGF and PDGFB) and a decrease in tumor growth. Selective HIF2 antagonists PT2399, PT2385, and PT2977 are under investigation ${ }^{20-22}$. PT2399 has been shown to cause regression in preclinical models (cell line and tumorgraft/ patient-derived xenograft) of pVHL-defective ccRCC $^{20,21}$. PT2385 has been evaluated as monotherapy in a phase 1 study in patients with metastatic ccRCC and has been shown to have a favorable safety profile and early evidence of efficacy ${ }^{22}$. PT2977, a more potent HIF2a antagonist, is being investigated in phase 1 clinical trials for the treatment of solid tumors and ccRCC and in a phase 2 clinical trial for the treatment of patients with VHL disease. 


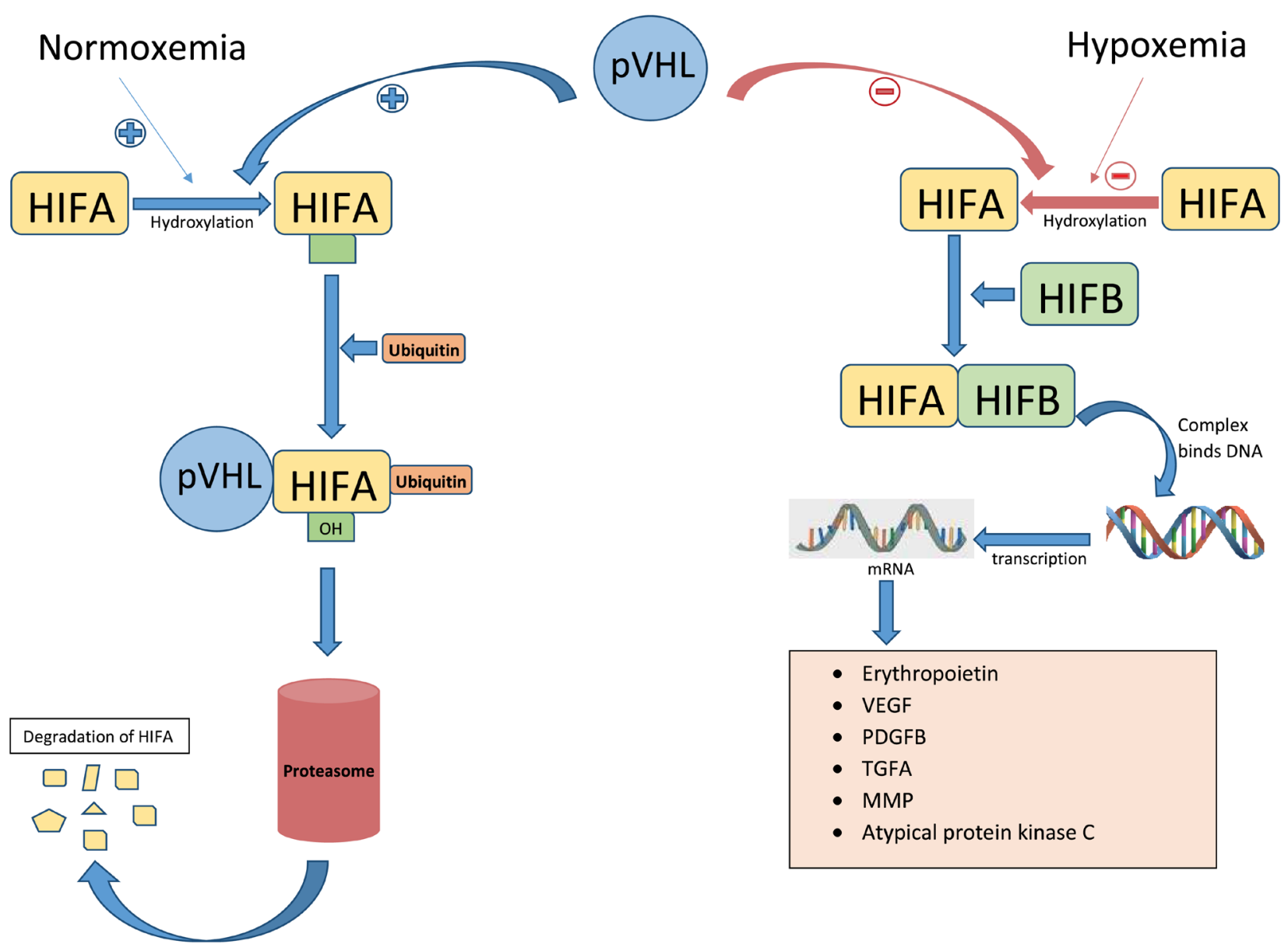

Figure 1. VHL/HIF axis. Under normal oxygen tension, HIF1A and HIF2A are hydroxylated on proline residues and bind the pVHL, resulting in the polyubiquitination of HIFA, which targets it for proteasomal degradation. Under conditions of hypoxemia or in the absence of pVHL, hydroxylation of HIF1A and HIF2A does not occur and HIFA accumulates and dimerizes with HIFB and acts as a transcription factor, resulting in increased mRNA levels coding for VEGF, PDGFB, TGFA, erythropoietin, and extracellular matrix protein. HIFA, hypoxia-inducible factor alpha; HIFB, hypoxia-inducible factor beta; MMP, matrix metalloproteinase protein; mRNA, messenger RNA; PDGFB, platelet-derived growth factor beta; pVHL, protein of Von Hippel-Lindau gene; TGFA, transforming growth factor alpha; VEGF, vascular endothelial growth factor.

\section{Protein polybromo-1 gene}

$P B R M-1$ is also a tumor suppressor gene that plays an important role in the pathogenesis of ccRCC. It encodes a protein called BAF180, which is a subunit of the nucleosome remodeling complex. The nucleosome remodeling complex is a complex group of proteins that control the expression of certain genes by accessing the condensed part of the DNA. It is unclear how BAF180 acts as a tumor suppressor protein; however, several animal studies have shown that it plays a role in controlling the cell cycle and replicative senescence. Re-introduction of PBRM-1 in PBRM-1-deficient cell lines typically produces cell cycle arrest. Thus, a mutated PBRM-1 gene would result in an abnormal/malfunctioning BAF180, which would result in unchecked cell growth and subsequent tumorigenesis ${ }^{23,24}$.

\section{BRCA1-associated protein-1}

BRCA1-associated protein-1 $(B A P-1)$ is a tumor suppressor gene located on $3 \mathrm{p}$. This gene is mutated in approximately $15 \%$ of ccRCC cases. BAP-1-mutated tumors tend to be more aggressive and are generally related to a worse prognosis ${ }^{25}$. Like other tumor suppressor genes, $B A P-1$ plays a role in the suppression of cell proliferation. It does so by interacting with a transcription protein called host cell factor-1 (HCF-1). HCF-1 in turn binds with several transcription factors, resulting in the inhibition of cell proliferation. A mutated BAP-1 protein is unable to interact with $\mathrm{HCF}-1$; as a result, the inhibitory effects of $\mathrm{HCF}-1$ on cell proliferation are $\operatorname{lost}^{26}$.

\section{The mTOR pathway}

The mammalian target of rapamycin (mTOR) is a protein kinase that is encoded by the MTOR gene. It plays an important role in the regulation of the cell cycle and has been a therapeutic target of interest in many other cancers as well. The mTOR-PI3K pathway starts with the binding of several growth factors to the cell surface, resulting in the activation of phosphatidylinositol3-kinase (PI3K) protein (Figure 2). Activated PI3K in turn 


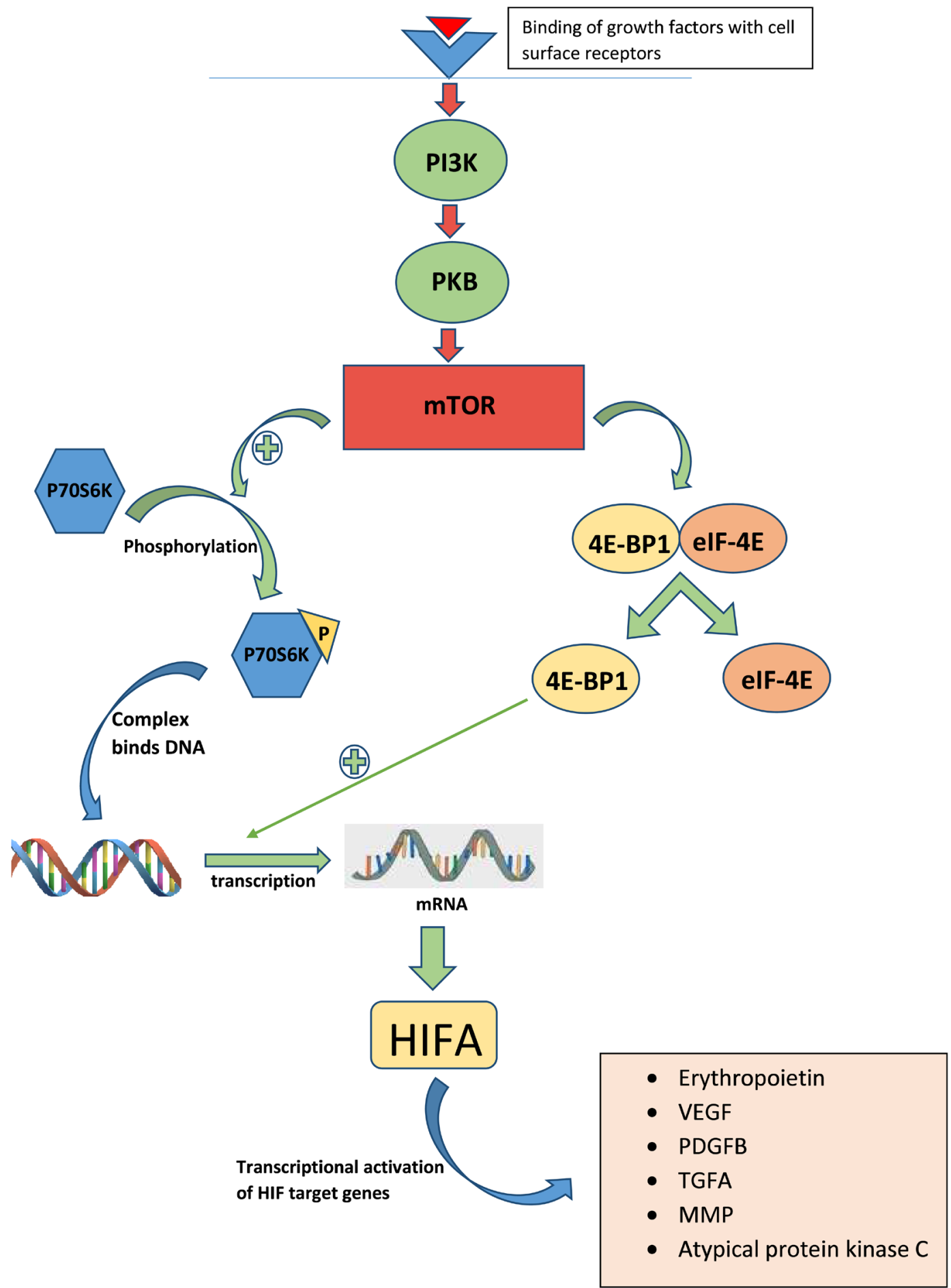

Figure 2. The mTOR-PI3K pathway. Binding of cell surface growth factors activates phosphatidylinositol-3-kinase (PI3K) protein, which in turn activates mTOR, creating mTOR complexes 1 and 2 (mTORC1 and mTORC2), resulting in the phosphorylation of P70S6K and 4EBP1/elF4E and increased production of angiogenic proteins such as VEGF, PDGF, and TGFB, leading to cell growth and tumor progression. 4E-BP1, 4E-binding protein 1; elF-4E, eukaryotic initiation factor-4E; HIF, hypoxia-inducible factor; HIFA, hypoxia-inducible factor alpha; MMP, matrix metalloproteinase; mRNA, messenger RNA; mTOR, mammalian target of rapamycin; PDGFB, platelet-derived growth factor beta; PI3K, phosphatidylinositol-3-kinase; PKB, protein kinase B; TGFA, transforming growth factor alpha; VEGF, vascular endothelial growth factor. 
activates mTOR, creating mTOR complexes 1 and 2 (mTORC1 and mTORC2), which lead to the phosphorylation of P70S6K and 4E-BP1/eukaryotic translation initiation factor 4E (4E-BP1/ eIF4E). The phosphorylated P70SK migrates to the nucleus and initiates the transcription of mRNA coding for the HIFA protein, which, as mentioned above, has the ability to increase the production of angiogenic proteins such as VEGF, PDGF, and $\mathrm{TGFB}^{27-29}$. Phosphorylation of the translational regulator eIF4E-binding protein 1 (4E-BP1) also mediates the effects of oncogenic Akt signaling on mRNA translation, cell growth, and tumor progression ${ }^{29}$.

Everolimus and temsirolimus are mTOR inhibitors that are approved for the treatment of metastatic $\mathrm{ccRCC}^{30,31}$. Additionally, the combination of lenvatinib (VEGFR inhibitor) and everolimus (mTOR inhibitor) has been approved for the treatment of metastatic $\mathrm{RCC}$ in the second- and subsequent-line setting.

The role of the immune system in renal cell carcinoma The cytotoxic component of the immune system plays a vital role in the recognition and subsequent rejection of several different types of cancer, including RCC. Unfortunately, this innate system is not always adequate in attacking and eliminating cancer. In order to survive the immune response, the cancer cells develop certain proteins on their cell surface, which help them fight off the cytotoxic $\mathrm{T}$ cells by certain pathways. One such pathway is the programmed death-1 (PD-1) pathway.

Under normal circumstances, the cytotoxic immune system is designed to recognize the "foreign antigens" present on the surface of cancer cells. This should lead to the activation of cytotoxic $\mathrm{T}$ lymphocytes, resulting in the release of cytokines such as interferons, interleukin-2, and tumor necrosis factor. These cytokines are directly responsible for the death of cancer cells. From a therapeutic standpoint, both interferon-alpha and interleukin-2 have historically been used for the treatment of ccRCC, although their use has diminished with the advent of effective and better-tolerated alternatives ${ }^{32,33}$. Immune T-cell infiltration is a prevalent characteristic of ccRCCs and represents an important target for immune checkpoint inhibitor therapy ${ }^{1,34}$.

\section{The programmed death-1 receptor pathway}

The PD-1 receptor is a cell membrane protein present on the surface of cytotoxic $\mathrm{T}$ lymphocytes (CD8 $\mathrm{T}$ cells). The proteins that activate PD-1 are also cell surface proteins called programmed death ligand-1 and -2 (PD-L1 and PD-L2). PD-L1 is present on the surface of antigen-presenting cells and certain malignant cells, including RCC cells. The major function of PD-1, after being activated by binding PD-L1, is to suppress the cytotoxic immune system by inducing apoptosis of the cytotoxic $\mathrm{T}$ lymphocyte. This normally prevents an uncontrolled and unchecked autoimmune response when the body is exposed to a foreign antigen (such as a virus or bacterium). Thus, PD-1 is an "anti-immune" protein, the stimulation of which suppresses the immune system and decreases the number of cytotoxic $\mathrm{T}$ cells attacking foreign antigens and cancer cells (Figure 3 ).
Several cancers, including ccRCC, express PD-L1 on their surface. The expression of PD-L1 allows these cancers to escape the cytotoxic immune response by inducing the apoptosis of cytotoxic $\mathrm{T}$ lymphocytes. This discovery has led to the development of antibodies that target and block PD-1 and PD-L1. The PD-1-blocking antibodies currently available are nivolumab and pembrolizumab. Nivolumab is currently approved for the treatment of metastatic ccRCC in the second-line setting ${ }^{35,36}$. Atezolizumab and avelumab are PD-L1-blocking monoclonal antibodies that are also under investigation for metastatic ccRCC.

CTLA-4 is a protein receptor present on the surface of cytotoxic $\mathrm{T}$ lymphocytes, and the primary function is downregulation of the immune system (similar to the PD-1/PD-L1 pathway) but by a different mechanism. An inhibitor of this receptor, called ipilimumab, in combination with PD-1/PD-L1 inhibitors, is under investigation and has shown promising results for the treatment of metastatic $\mathrm{RCC}^{37}$.

OX-40 is another "pro-inflammatory" protein present on the surface of cytotoxic $\mathrm{T}$ lymphocytes. The stimulation of this receptor results in the activation of the immune system (similar to that seen with PD-1/PD-L1 inhibition). OX-40 agonists in combination with PD-1 inhibitors are under investigation for the treatment of $\mathrm{RCC}^{38}$.

\section{Metabolic pathways and targets in renal cell carcinoma}

Altered metabolic pathways in cancer cells play a key role in their survival. These pathways also help cancer cells escape different levels of stress imposed on them by the immune system as well as various drugs. Targeting various metabolic pathways in RCC is an active area of research in oncology $y^{39,40}$.

\section{The glutaminase pathway}

Glutamine is an important amino acid in many cancer cells (including ccRCC cells) and is indirectly required by these cells for the synthesis of DNA. Cancer cells metabolize glutamine differently than do normal cells and require an enzyme called glutaminase. This enzyme converts glutamine to glutamate, which in turn increases the production of aspartate through the Krebs cycle. Aspartate plays a key role in the synthesis of pyrimidines in these cells and is required for maturation. In VHL-mutated/deficient cells, glutamine is also required for the synthesis of essential lipids, citrate, and glutathione, the latter of which is the key anti-oxidant molecule generated by cells to combat oxidative stress ${ }^{41}$. Therefore, inhibition of this pathway results in both cell cycle arrest (by decreasing pyrimidine synthesis required for DNA formation) and an inability of these cells to fight oxidative stress. These findings have led to the development of drugs targeting this pathway, which are under investigation. For example, CB-839 is a glutaminase inhibitor that is being studied in clinical trials for several solid tumors, including ccRCC $^{42,43}$.

\section{Other metabolic pathways and targets}

Glucose metabolism in cancer cells is also an area of clinical interest in this field. GLUT-1 is a glucose transporter that is 

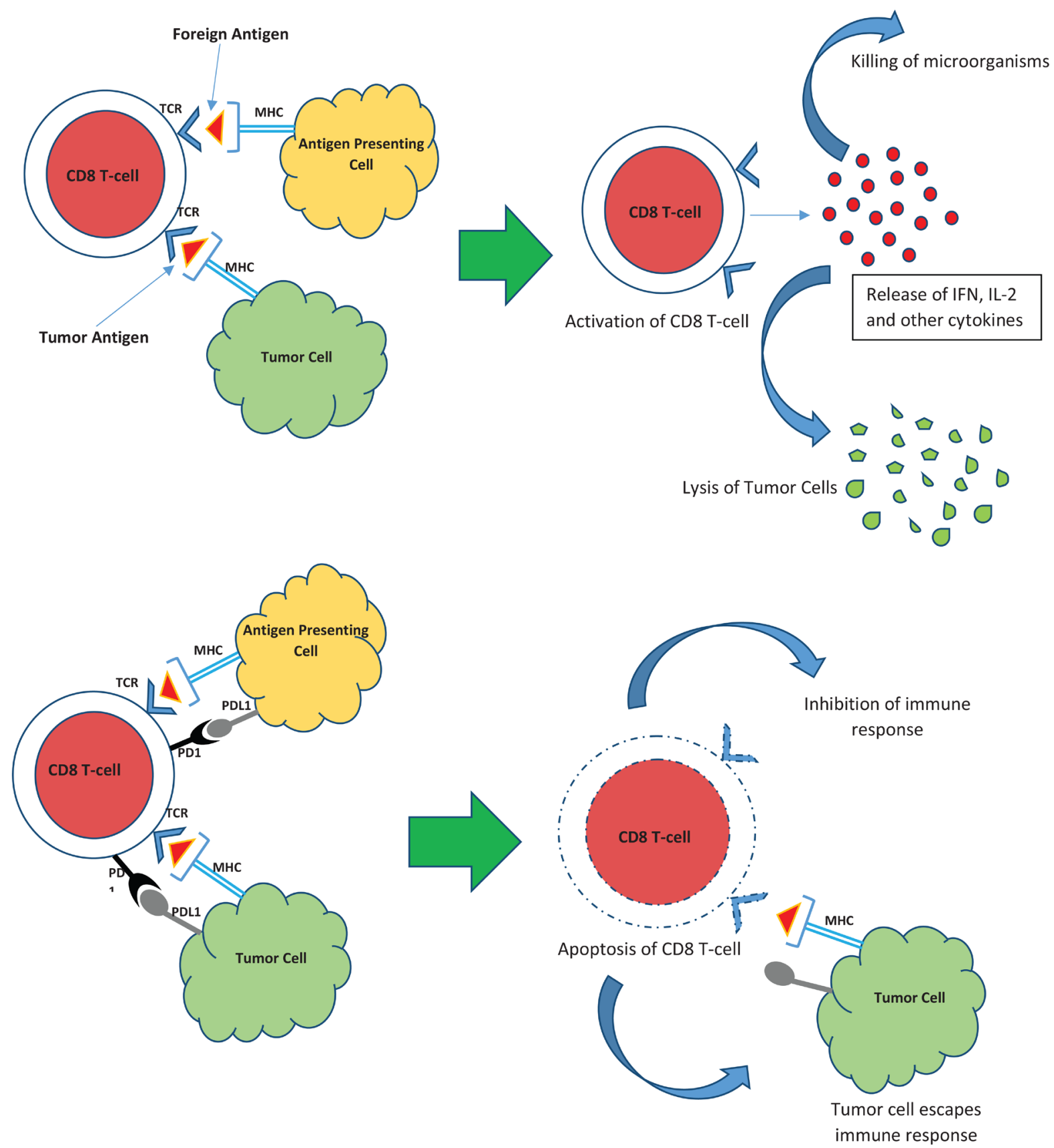

Figure 3. The programmed death-1 receptor pathway. Recognition of foreign or tumor antigens normally results in the activation of CD8 T cells, leading to the killing of viruses or bacteria or the lysis of tumor cells. The programmed death-1 (PD-1) receptor is a cell membrane protein present on the surface of CD8 T cells, which, upon interacting with PD-L1 and PD-L2 on the surface of tumor cells, results in the suppression of the cytotoxic immune response, leading to tumor escape.IFN, interferon; IL-2, interleukin-2; MHC, major histocompatibility complex; PD-1, programmed death-1; PD-L1, programmed death ligand-1; TCR, T-cell receptor. 
responsible for the uptake of glucose by RCC cells. Several drugs blocking this transporter have been shown to be active in $\mathrm{RCC}^{44,45}$. Studies have demonstrated that, unlike in normal cells, glycolysis is the major source of glucose in cancer cells, even in the presence of sufficient oxygen (aerobic glycolysis) ${ }^{46}$. As a result, several inhibitors of glycolytic enzymes have been investigated because of their activity in cancer cells, including RCC cells ${ }^{47,48}$. Similarly, pyruvate dehydrogenase inhibitors have shown activity in preclinical RCC xenografts ${ }^{49,50}$.

\section{Other novel approaches and combinations}

Despite our extensive knowledge and understanding of the biology of this cancer, metastatic RCC continues to lead to a high number of deaths in the modern era. With the discovery of pathways outlined in this article, many research studies are now geared toward combining drugs that target different pathways in ccRCC. Combination studies in metastatic ccRCC that pair VEGF inhibition and checkpoint inhibition include bevacizumab plus atezolizumab, axitinib plus pembrolizumab, and nivolumab plus ipilimumab plus cabozantinib. There are also studies of combination immunotherapies targeting PD-1 and PD-L1 or targeting PD-L1 and OX40.

In addition, the glutaminase inhibitor CB-839 is being investigated in combination with anti-PD-1 antibody nivolumab as well as with the mTOR inhibitor everolimus and the VEGFR/MET inhibitor cabozantinib in separate clinical trials.

A better understanding of the biology and pathogenesis of ccRCC has revolutionized the treatment approach. Novel targets and combination strategies are under investigation with the hope of achieving longer and more durable responses and improving survival.
In summary, with a greater understanding of the pathogenesis of RCC, many therapeutic advances for metastatic disease have been introduced in the last decade. Such progress has led to improved survival for patients with advanced RCC. Much of the recent therapeutic development has focused on inhibition of the VEGFR and the mTOR pathways. Current and ongoing areas of research include the additional development of new immunotherapy targets, metabolic targeting, and combinational approaches to treat the disease.

\section{Competing interests}

ETL receives kidney cancer clinical trial funding from Argos, Bristol-Myers Squibb, Calithera, Genentech, Merck, Peloton, Pfizer, and Roche; has served as a consultant for Bristol-Myers Squibb; and serves on the Independent Data Monitoring Board for Calithera. ERK receives kidney cancer clinical trial funding from Bristol-Myers Squibb. TWF receives clinical trial funding from Bristol-Myers Squibb, Novartis, Pfizer, Bavarian Nordic, Cougar Biotechnology, Dendreon, GTx, Janssen Oncology, Medivation, Sanofi, Genentech, Roche, Exelixis, Aragon Pharmaceuticals, Sotio, Tokai Pharmaceuticals, Astra-Zeneca/ MedImmune, Lilly, Astellas, Agensys, and Seattle Genetics and has served as a consultant for GTx.

\section{Grant information}

ETL receives funding support from the National Institutes of Health/National Cancer Institute Paul Calabresi Award in Clinical Oncology Research (K12CA086913).

The funders had no role in study design, data collection and analysis, decision to publish, or preparation of the manuscript.
1. $\quad F$ Hsieh JJ, Purdue MP, Signoretti S, et al.: Renal cell carcinoma. Nat Rev Dis Primers. 2017; 3: 17009

PubMed Abstract | Publisher Full Text | F1000 Recommendation

2. Chow WH, Dong LM, Devesa SS: Epidemiology and risk factors for kidney cancer. Nat Rev Urol. 2010; 7(5): 245-57. PubMed Abstract | Publisher Full Text | Free Full Text

3. F Siegel RL, Miller KD, Jemal A: Cancer Statistics, 2017. CA Cancer J Clin 2017; 67(1): 7-30.

PubMed Abstract | Publisher Full Text | F1000 Recommendation

4. Thompson $\mathrm{RH}$, Ordonez MA, lasonos A, et al:: Renal cell carcinoma in young and old patients--is there a difference? J Urol. 2008; 180(4): 1262-6; discussion 1266. PubMed Abstract | Publisher Full Text | Free Full Text

5. Siegel R, Ward E, Brawley O, et al:: Cancer statistics, 2011: the impact of eliminating socioeconomic and racial disparities on premature cancer deaths. CA Cancer J Clin. 2011; 61(4): 212-36. PubMed Abstract | Publisher Full Text

6. F Siegel R, Naishadham D, Jemal A: Cancer statistics, 2012. CA Cancer J Clin 2012; 62(1): 10-29.

PubMed Abstract | Publisher Full Text | F1000 Recommendation

7. Motzer RJ, Jonasch E, Agarwal N, et al.: Kidney Cancer, Version 2.2017, NCCN Clinical Practice Guidelines in Oncology. J Natl Compr Canc Netw. 2017; 15(6):
804-34.

PubMed Abstract | Publisher Full Text

8. Beroukhim R, Brunet JP, Di Napoli A, et al:: Patterns of gene expression and copy-number alterations in von-hippel lindau disease-associated and sporadic clear cell carcinoma of the kidney. Cancer Res. 2009; 69(11): 4674-81. PubMed Abstract | Publisher Full Text | Free Full Text

9. Foster K, Prowse A, van den Berg A, et al:: Somatic mutations of the von Hippel-Lindau disease tumour suppressor gene in non-familial clear cell renal carcinoma. Hum Mol Genet. 1994; 3(12): 2169-73. PubMed Abstract | Publisher Full Text

10. Gnarra JR, Tory $\mathrm{K}$, Weng $\mathrm{Y}$, et al:: Mutations of the VHL tumour suppressor gene in renal carcinoma. Nat Genet. 1994; 7(1): 85-90. PubMed Abstract | Publisher Full Text

11. Yao M, Yoshida M, Kishida T, et al:: VHL tumor suppressor gene alterations associated with good prognosis in sporadic clear-cell renal carcinoma. $J$ Nat Cancer Inst. 2002; 94(20): 1569-75

PubMed Abstract | Publisher Full Text

12. Nickerson ML, Jaeger $E$, Shi $Y$, et al:: Improved identification of von HippelLindau gene alterations in clear cell renal tumors. Clin Cancer Res. 2008; 14(15): 4726-34.

PubMed Abstract | Publisher Full Text | Free Full Text

13. Kaelin WG Jr: Molecular basis of the VHL hereditary cancer syndrome. Nat Rev 
Cancer. 2002; 2(9): 673-82. PubMed Abstract | Publisher Full Text

14. Barry RE, Krek W: The von Hippel-Lindau tumour suppressor: a multi-faceted inhibitor of tumourigenesis. Trends Mol Med. 2004; 10(9): 466-72. PubMed Abstract | Publisher Full Text

15. Kim WY, Kaelin WG: Role of VHL gene mutation in human cancer. $J$ Clin Oncol. 2004; 22(24): 4991-5004.

PubMed Abstract | Publisher Full Text

16. Pugh CW, Ratcliffe PJ: Regulation of angiogenesis by hypoxia: role of the HIF system. Nat Med. 2003; 9(6): 677-84. PubMed Abstract | Publisher Full Text

17. Maxwell PH, Pugh CW, Ratcliffe PJ: Activation of the HIF pathway in cancer. Curr Opin Genet Dev. 2001; 11(3): 293-9. PubMed Abstract | Publisher Full Text

18. $\mathrm{F}$ Motzer RJ, Hutson TE, Tomczak $\mathrm{P}$, et al: Sunitinib versus interferon alfa in metastatic renal-cell carcinoma. N Engl J Med. 2007; 356(2): 115-24. PubMed Abstract | Publisher Full Text | F1000 Recommendation

19. F Motzer RJ, Hutson TE, Cella D, et al:: Pazopanib versus sunitinib in metastatic renal-cell carcinoma. N Engl J Med. 2013; 369(8): 722-31. PubMed Abstract | Publisher Full Text | F1000 Recommendation

20. $\mathrm{F}$ Chen $\mathrm{W}$, Hill $\mathrm{H}$, Christie A, et al.: Targeting renal cell carcinoma with a HIF-2 antagonist. Nature. 2016; 539(7627): 112-7. PubMed Abstract | Publisher Full Text | Free Full Text | F1000 Recommendation

21. F Cho H, Du X, Rizzi JP, et al:: On-target efficacy of a HIF-2 $\alpha$ antagonist in preclinical kidney cancer models. Nature. 2016; 539(7627): 107-11. PubMed Abstract | Publisher Full Text | Free Full Text | F1000 Recommendation

22. Courtney KD, Infante JR, Lam ET, et al.: Phase I Dose-Escalation Trial of PT2385, a First-in-Class Hypoxia-Inducible Factor-2 $\alpha$ Antagonist in Patients With Previously Treated Advanced Clear Cell Renal Cell Carcinoma. J Clin Oncol. 2017: JCO2017742627. PubMed Abstract | Publisher Full Text

23. Thompson M: Polybromo-1: the chromatin targeting subunit of the PBAF complex. Biochimie. 2009; 91(3): 309-19. PubMed Abstract | Publisher Full Text | Free Full Text

24. Brugarolas J: PBRM1 and BAP1 as novel targets for renal cell carcinoma. Cancer J. 2013; 19(4): 324-32. PubMed Abstract | Publisher Full Text | Free Full Text

25. Kapur P, Peña-Llopis S, Christie A, et al.: Effects on survival of BAP1 and PBRM1 mutations in sporadic clear-cell renal-cell carcinoma: a retrospective analysis with independent validation. Lancet Oncol. 2013; 14(2): 159-67. PubMed Abstract | Publisher Full Text | Free Full Text

26. Peña-Llopis $\mathrm{S}$, Vega-Rubín-de-Celis $\mathrm{S}$, Liao A, et al.: BAP1 loss defines a new class of renal cell carcinoma. Nat Genet. 2012; 44(7): 751-9. PubMed Abstract | Publisher Full Text | Free Full Text

27. Zoncu R, Efeyan A, Sabatini DM: mTOR: from growth signal integration to cancer, diabetes and ageing. Nat Rev Mol Cell Biol. 2011; 12(1): 21-35. PubMed Abstract | Publisher Full Text | Free Full Text

28. Zarogoulidis $\mathrm{P}$, Lampaki $\mathrm{S}$, Turner JF, et al:: mTOR pathway: A current, up-todate mini-review (Review). Oncol Lett. 2014; 8(6): 2367-70. PubMed Abstract | Publisher Full Text | Free Full Text

29. Laplante M, Sabatini DM: mTOR signaling in growth control and disease. Cell. 2012; 149(2): 274-93.

PubMed Abstract | Publisher Full Text | Free Full Text

30. F Motzer RJ, Escudier B, Oudard S, et al:: Efficacy of everolimus in advanced renal cell carcinoma: a double-blind, randomised, placebo-controlled phase III trial. Lancet. 2008; 372(9637): 449-56. PubMed Abstract | Publisher Full Text | F1000 Recommendation

31. Rini BI, Bellmunt J, Clancy J, et al:: Randomized phase III trial of temsirolimus and bevacizumab versus interferon alfa and bevacizumab in metastatic renal cell carcinoma: INTORACT trial. J Clin Oncol. 2014; 32(8): 752-9. PubMed Abstract | Publisher Full Text

32. Klapper JA, Downey SG, Smith FO, et al:: High-dose interleukin-2 for the treatment of metastatic renal cell carcinoma : a retrospective analysis of response and survival in patients treated in the surgery branch at the National Cancer Institute between 1986 and 2006. Cancer. 2008; 113(2): 293-301. PubMed Abstract | Publisher Full Text | Free Full Text

33. Fyfe G, Fisher RI, Rosenberg SA, et al:: Results of treatment of $\mathbf{2 5 5}$ patients with metastatic renal cell carcinoma who received high-dose recombinant interleukin-2 therapy. J Clin Oncol. 1995; 13(3): 688-96. PubMed Abstract | Publisher Full Text

34. $\quad F$ Şenbabaoğlu $Y$, Gejman RS, Winer AG, et al:: Tumor immune microenvironment characterization in clear cell renal cell carcinoma identifies prognostic and immunotherapeutically relevant messenger RNA signatures. Genome Biol. 2016; 17(1): 231.

PubMed Abstract | Publisher Full Text | Free Full Text | F1000 Recommendation

35. F Motzer RJ, Rini BI, McDermott DF, et al:: Nivolumab for Metastatic Renal Cell Carcinoma: Results of a Randomized Phase II Trial. J Clin Oncol. 2015; 33(13): $1430-7$.

PubMed Abstract | Publisher Full Text | Free Full Text | F1000 Recommendation

36. McDermott DF, Drake CG, Sznol M, et al: Survival, Durable Response, and Long-Term Safety in Patients With Previously Treated Advanced Renal Cell Carcinoma Receiving Nivolumab. J Clin Oncol. 2015; 33(18): 2013-20. PubMed Abstract | Publisher Full Text | Free Full Text

37. F Hammers HJ, Plimack ER, Infante JR, et al:: Safety and Efficacy of Nivolumab in Combination With Ipilimumab in Metastatic Renal Cell Carcinoma: The CheckMate 016 Study. J Clin Oncol. 2017; 35(34): 3851-8. PubMed Abstract | Publisher Full Text | F1000 Recommendation

38. Linch SN, McNamara MJ, Redmond WL: OX40 Agonists and Combination Immunotherapy: Putting the Pedal to the Metal. Front Oncol. 2015; 5: 34 PubMed Abstract | Publisher Full Text | Free Full Text

39. Pinthus $\mathrm{JH}$, Whelan KF, Gallino D, et al:: Metabolic features of clear-cell renal cell carcinoma: mechanisms and clinical implications. Can Urol Assoc J. 2011; 5(4): 274-82. PubMed Abstract | Free Full Text

40. F van der Mijn JC, Panka DJ, Geissler AK, et al.: Novel drugs that target the metabolic reprogramming in renal cell cancer. Cancer Metab. 2016; 4: 14 PubMed Abstract | Publisher Full Text | Free Full Text | F1000 Recommendation

41. F Okazaki A, Gameiro PA, Christodoulou D, et al:: Glutaminase and poly(ADPribose) polymerase inhibitors suppress pyrimidine synthesis and $\mathrm{VHL}$ deficient renal cancers. J Clin Invest. 2017; 127(5): 1631-45. PubMed Abstract | Publisher Full Text | Free Full Text | F1000 Recommendation

42. F Abu Aboud O, Habib SL, Trott J, et al:: Glutamine Addiction in Kidney Cancer Suppresses Oxidative Stress and Can Be Exploited for Real-Time Imaging. Cancer Res. 2017; 77(23): 6746-58.

PubMed Abstract | Publisher Full Text | Free Full Text | F1000 Recommendation

43. Meric-Bernstam F, Tannir NM, Mier JW, et al.: Phase 1 study of CB-839, a small molecule inhibitor of glutaminase (GLS), alone and in combination with everolimus (E) in patients (pts) with renal cell cancer (RCC). J Clin Oncol. 2016; 34(15_suppl): 4568. Reference Source

44. F Chan DA, Sutphin PD, Nguyen P, et al.: Targeting GLUT1 and the Warburg effect in renal cell carcinoma by chemical synthetic lethality. Sci Transl Med. 2011; 3(94): 94ra70.

PubMed Abstract | Publisher Full Text | Free Full Text | F1000 Recommendation

45. Liu Y, Cao Y, Zhang W, et al.: A small-molecule inhibitor of glucose transporter 1 downregulates glycolysis, induces cell-cycle arrest, and inhibits cancer cell growth in vitro and in vivo. Mol Cancer Ther. 2012; 11(8): 1672-82. PubMed Abstract | Publisher Full Text

46. WARBURG O: On respiratory impairment in cancer cells. Science. 1956; 124(3215): 269-70. PubMed Abstract

47. Clem B, Telang S, Clem A, et al:: Small-molecule inhibition of 6-phosphofructo2-kinase activity suppresses glycolytic flux and tumor growth. Mol Cancer Ther. 2008; 7(1): 110-20.

PubMed Abstract | Publisher Full Text

48. Clem BF, O'Neal J, Tapolsky G, et al:: Targeting 6-phosphofructo-2-kinase (PFKFB3) as a therapeutic strategy against cancer. Mol Cancer Ther. 2013; 12(8): 1461-70. PubMed Abstract | Publisher Full Text | Free Full Text

49. F Papandreou I, Cairns RA, Fontana L, et al.: HIF-1 mediates adaptation to hypoxia by actively downregulating mitochondrial oxygen consumption. Cell Metab. 2006; 3(3): 187-97.

PubMed Abstract | Publisher Full Text | F1000 Recommendation

50. F Kinnaird A, Dromparis $\mathrm{P}$, Saleme B, et al:: Metabolic Modulation of Clearcell Renal Cell Carcinoma with Dichloroacetate, an Inhibitor of Pyruvate Dehydrogenase Kinase. Eur Urol. 2016; 69(4): 734-44. PubMed Abstract | Publisher Full Text | F1000 Recommendation 


\section{Open Peer Review}

\section{Current Peer Review Status:}

\section{Editorial Note on the Review Process}

Faculty Reviews are review articles written by the prestigious Members of Faculty Opinions. The articles are commissioned and peer reviewed before publication to ensure that the final, published version is comprehensive and accessible. The reviewers who approved the final version are listed with their names and affiliations.

\section{The reviewers who approved this article are:}

\section{Version 1}

\section{James J. Hsieh}

Molecular Oncology, Department of Medicine, Siteman Cancer Center, Washington University, St.

Louis, MO, USA

Competing Interests: No competing interests were disclosed.

\section{Mehdi Mollapour}

Department of Biochemistry and Molecular Biology, SUNY Upstate Medical University, Syracuse, NY, USA

Competing Interests: No competing interests were disclosed.

The benefits of publishing with F1000Research:

- Your article is published within days, with no editorial bias

- You can publish traditional articles, null/negative results, case reports, data notes and more

- The peer review process is transparent and collaborative

- Your article is indexed in PubMed after passing peer review

- Dedicated customer support at every stage

For pre-submission enquiries, contact research@f1000.com

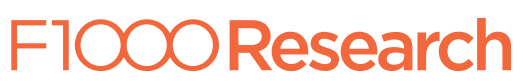

